Exhibit of samples of glass showing filming

This content has been downloaded from IOPscience. Please scroll down to see the full text. 1918 Trans. Opt. Soc. 2040

(http://iopscience.iop.org/1475-4878/20/2/304)

View the table of contents for this issue, or go to the journal homepage for more

Download details:

IP Address: 129.96.252.188

This content was downloaded on 03/10/2015 at 09:09

Please note that terms and conditions apply. 


\title{
EXHIBIT OF SAMPLES OF GLASS SHOWING FILMING
}

\author{
BY W. H. WITHEY, B.A. \\ (From the National Physical Laboratory) \\ Exhibited, I4th November, I918
}

THE samples of optical glass exhibited were tested and classified in December, I916, by exposing the broken surfaces to a moist atmosphere at $18^{\circ} \mathrm{C}$. for one week and estimating by means of iodeosin the alkali liberated. Nos. I, 2, 4, and 5 gave excellent results, whilst No. 3 was very distinctly inferior $\left(\mathrm{H}_{5}\right)$. Since December, I916, the specimens of glass have been exposed to the weather on an open roof. The result of the test is that No. 3 is now distinctly the best, No. 4 comes next, No. $\mathrm{I}$ is almost as good, while No. 2 , which previously gave results equal to No. I, is seriously tarnished. Nos. I and 2 are of similar composition, as are Nos. 4 and 5 .

The conclusion to be drawn is that the iodeosin test alone does not seem to be sufficient from the point of view of filming, and other tests seem to be desirable. 